\title{
Host status of soybean genotypes to Meloidogyne species
}

\author{
Luis Alejandro Yánez Márquez ${ }^{1}$ Daniele de Brum ${ }^{1}$ (i) Cesar Bauer Gomes ${ }^{2}$ (i) \\ Ana Claudia Barneche de Oliveira ${ }^{2}$ (i) Eduardo Heller $^{1}$ (i) Esmael Luis Neuschrank ${ }^{1}$ \\ Jerônimo Vieira de Araújo Filho ${ }^{*}$ (1)
}

${ }^{1}$ Universidade Federal de Pelotas (UFPel), Faculdade de Agronomia Eliseu Maciel, 96050-500, Capão do Leão, RS, Brasil. E-mail: jeronimo.labnema@gmail.com. "Corresponding author.

${ }^{2}$ Embrapa Clima Temperado, Rod. BR 392, km 78, 6010-971, Pelotas, RS, Brasil.

ABSTRACT: This study aimed to evaluate the host status of soybean genotypes to Meloidogyne javanica (Est J3), Meloidogyne sp.0 (Est R0), and M. graminicola (Est VS1). In the first experiment, all tested genotypes (BMX Potência RR, BMX Valente RR, BMX Icone IPRO, PELBR10-6049 RR, and TECIRGA 6070 RR) were susceptible to M. javanica, with reproduction factor (RF) $>1.0$, and resistant to Meloidogyne sp.0 (0.01 > RF < 0.15), whereas in the second experiment, all genotypes (BRS 246 RR, PELBR11-6038 RR, PELBR11-6001 RR, PELBR10-6005 RR, BMX Apolo RR, PELBR11-6028 RR, PF11651, PF103251, PELBR11-6035 RR, PELBR10-6050 RR, PELBR11-6042 RR, PELBR10-6017 RR, PELBR11-6007 RR, PELBR10-6016 RR, and PELBR10-6049 RR) were resistant to M. graminicola (0.06 > RF < 0.43). Key words: plant resistance, soybean, phytonematodes, Rio Grande do Sul.

Reação de genótipos de soja a espécies de Meloidogyne

RESUMO: No presente estudo objetivou-se avaliar a reação de genótipos de soja a Meloidogyne javanica (Est J3), Meloidogyne sp.0 (Est R0) e M. graminicola (Est VS1). No primeiro experimento, todos os genótipos (BMX Potência RR, BMX Valente RR, BMX Icone IPRO, PELBR10-6049 RR, and TECIRGA 6070 RR) testados mostraram-se suscetiveis a M. javanica, com fator de reprodução (FR) >1.0, e resistentes a Meloidogyne sp.0 (0.01 > FR < 0.15), enquanto no segundo experimento, todos os genótipos (BRS 246 RR, PELBR11-6038 RR, PELBR11-6001 RR, PELBR10-6005 RR, BMX Apolo RR, PELBR11-6028 RR, PF11651, PF103251, PELBR11-6035 RR, PELBR10-6050 RR, PELBR11-6042 RR, PELBR10-6017 RR, PELBR11-6007 RR, PELBR10-6016 RR, and PELBR10-6049 RR) testados comportaram-se como resistentes a $M$. graminicola $(0.06>F R<0.43)$.

Palavras-chave: resistência de plantas, soja, fitonematoides, Rio Grande do Sul.

Soybean (Glycine max L. Merril) is one of the most important legumes crops in the world, contributing to $25 \%$ of the edible oil production and providing approximately $67 \%$ of the protein concentrate for animal feed worldwide (AGARWAL et al., 2013).

However, intensive planting and expansion of croplands to new areas have intensified phytosanitary problems, particularly those related to plant parasitic nematodes. In this context, the species Meloidogyne javanica and M. incognita are widely distributed in the soybean growing areas of Brazil (DIAS et al., 2010). Other species have been reported in different regions of the world, such as $M$. graminicola in China (LONG et al., 2017). This must be taken into consideration when planting soybeans in areas previously destined for the rice sector. In addition, recently, there have been frequent reports of an atypical population, called Meloidogyne sp.0, in southern Brazil (MATTOS et al., 2017). Therefore, the objective of this study was to evaluate the response of soybean genotypes to M. javanica, Meloidogyne sp.0, and $M$. graminicola, under greenhouse conditions.

Two experiments were conducted in a greenhouse $\left(25^{\circ} \mathrm{C} \pm 5^{\circ} \mathrm{C}\right)$ at Embrapa Clima Temperado - Pelotas / RS $\left(31^{\circ} 42^{\prime} \mathrm{S} 52^{\circ} 24^{\prime} \mathrm{W}\right)$, from November 2018 to February 2019 (70 days). In the first experiment, five genotypes were evaluated against 
M. javanica (Est J3) and Meloidogyne sp.0 (Est R0) (Tables 1 and 2), and in the second experiment, fifteen genotypes were evaluated against $M$. graminicola (Est VS1) (Table 3). The first experiment was performed in a completely randomized factorial design (5 genotypes $\times 2$ species $\times$ with or without nematodes). The second experiment was also performed in a completely randomized design with 15 genotypes. Tomato (Lycopersicon esculentum Mill. 'Santa Cruz') seedlings for $M$. javanica, and irrigated rice (EPAGRI SCS112 and BR IRGA 403) for Meloidogyne sp.0 and $M$. graminicola, were included to verify the viability of the inoculum.

Specimens of Meloidogyne were obtained following the methodology of COOLEN and D'HERDE (1972). Ten days after emergence, each seedling, grown in a 3,500 $\mathrm{mL}$ pot containing previously sterilized soil, was inoculated with a suspension containing 5,000 specimens (eggs + J2) from each Meloidogyne population separately (initial population $=\mathrm{Pi}$ ). Two evaluations were performed, 30 and 60 days after inoculation (dai), to determine the average chlorophyll content of the leaves, using a portable chlorophyll meter (SPAD-502 Plus ${ }^{\circledR}$, KONICA MINOLTA OPTICS, INC., Marunouchi, Chiyoda, Tokyo, Japan, ${ }^{\circ} 2009$ ). The plants were removed from the soil after 60 days, and the fresh mass of the root system (FMRS), fresh mass of the aerial part (FMAP), and number of galls (NG) were determined. Subsequently, the nematodes were then extracted from the roots according to the aforementioned methodology, and the final population (Pf) and reproduction factor of each nematode species $(\mathrm{RF}=\mathrm{Pf} / \mathrm{Pi})$ were estimated. Genotypes were classified as resistant $(\mathrm{R} ; \mathrm{RF}<1.0)$ or susceptible $(\mathrm{S}$; RF > 1.0) (OOSTENBRINK, 1966).

For data from the first experiment, the values of the different variables were subjected to analysis of variance (ANOVA) and compared with Tukey's test (1953) $(\alpha=0.05)$, using SAS ${ }^{\circledR}$ software (SAS 9.3, SAS Institute, Cary, North Carolina, USA). Data from the second experiment were compared with the Scott-Knott grouping test (1974) $(\alpha=0.05)$, using the SASM program.

There were significant interactions between the inoculation-genotype factors for the chlorophyll content assessed 30 dai in plants inoculated with Meloidogyne sp.0. For the effect of inoculation within each genotype, differences were observed only for BMX Potência RR. In plants inoculated with $M$. javanica, the effects were significant only for genotypes; however, after 60 dai, the effects were significant for both genotypes and inoculation. The chlorophyll content did not differ between the genotypes inoculated with $M$. javanica and Meloidogyne sp.0 (Table 1).

On analysis of the FMAP data, a significant interaction between factors was observed for Meloidogyne sp.0. In case of the effect of inoculation on FMAP within each genotype, a significative increase

Table 1 - Leaf chlorophyll content, and fresh mass of the aerial part (FMAP) and root system (FMRS) of soybean genotypes inoculated with Meloidogyne javanica and Meloidogyne sp.0, 30 and 60 days after inoculation.

\begin{tabular}{|c|c|c|c|c|c|c|c|c|}
\hline \multirow{4}{*}{ Genotypes } & \multicolumn{8}{|c|}{ 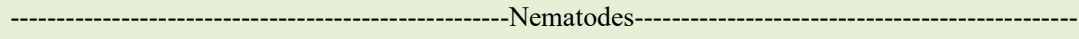 } \\
\hline & \multicolumn{8}{|c|}{---------------------------------------------Meloidogyne javanica------------------------------------------- } \\
\hline & \multicolumn{2}{|c|}{ Chlorophyll 30} & \multicolumn{2}{|c|}{ Chlorophyll 60} & \multicolumn{2}{|c|}{ FMAP $(g)$} & \multicolumn{2}{|c|}{ FMRS $(g)$} \\
\hline & WN & IN & WN & $\mathrm{IN}$ & WN & IN & WN & IN \\
\hline BMX Potência RR & 40.2 & 37.5 & 24.6 & 28.6 & 105.5 & 113.8 & 94.7 & 127.3 \\
\hline PELBR10-6049 RR & 37.9 & 37.7 & 25.5 & 27.9 & 101.3 & 109.8 & 74.3 & 119.5 \\
\hline BMX Valente RR & 38.3 & 40.2 & 20.8 & 26.8 & 100.7 & 119.6 & 56.0 & 105.2 \\
\hline BMX Icone IPRO & 37.9 & 37.4 & 26.8 & 25.4 & 93.4 & 98.7 & 91.3 & 121.6 \\
\hline \multirow[t]{2}{*}{ TECIRGA 6070 RR } & 37.2 & 37.5 & 22.6 & 25.1 & 92.4 & 98.4 & 67.2 & 97.5 \\
\hline & \multicolumn{8}{|c|}{--------------------------------------------Meloidogyne sp.0-------------------------------------------------- } \\
\hline BMX Potência RR & 40.2 & 37.1 & 24.6 & 27.7 & 105.5 & 116.1 & 94.7 & 78.6 \\
\hline PELBR10-6049 RR & 37.9 & 38.7 & 25.5 & 27.3 & 101.3 & 121.5 & 74.3 & 84.0 \\
\hline BMX Valente RR & 38.3 & 40.3 & 20.8 & 28.1 & 100.7 & 121.6 & 56.0 & 70.0 \\
\hline BMX Icone IPRO & 37.9 & 36.8 & 26.8 & 28.6 & 93.4 & 105.5 & 91.3 & 115.8 \\
\hline TECIRGA 6070 RR & 37.2 & 36.7 & 22.6 & 24.7 & 92.4 & 96.5 & 67.2 & 101.4 \\
\hline
\end{tabular}

$\mathrm{WN}=$ without nematode; $\mathrm{IN}=$ inoculated with nematode; $\mathrm{g}=$ grams 
Table 2 - Response of soybean genotypes to Meloidogyne javanica and Meloidogyne sp.0.

\begin{tabular}{|c|c|c|c|}
\hline \multirow{3}{*}{ Genotypes } & \multicolumn{3}{|c|}{ 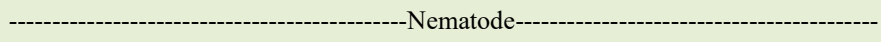 } \\
\hline & \multicolumn{3}{|c|}{ 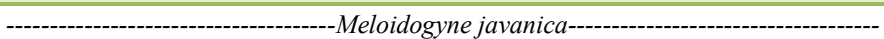 } \\
\hline & Number of Galls ${ }^{* *}$ & $\mathrm{RF}$ & Response \\
\hline TOMATO (Santa Cruz) ${ }^{1}$ & $613 c^{*}$ & $22.23 \mathrm{c}$ & \\
\hline PELBR10-6049 RR & $3214.33 \mathrm{a}$ & $12.47 \mathrm{c}$ & $\mathrm{S}$ \\
\hline BMX Valente RR & $1193.67 b$ & $43.56 \mathrm{ab}$ & $\mathrm{S}$ \\
\hline BMX Potência RR & $894.33 b$ & $49.52 \mathrm{a}$ & S \\
\hline TECIRGA 6070 RR & $511.33 \mathrm{c}$ & $22.23 \mathrm{c}$ & S \\
\hline BMX Icone IPRO & $499.67 \mathrm{c}$ & $28.25 b c$ & $\mathrm{~S}$ \\
\hline \multirow[t]{2}{*}{ CV $(\%)$} & 15.97 & 34.52 & \\
\hline & \multicolumn{3}{|c|}{ 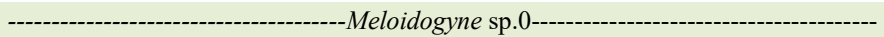 } \\
\hline RICE (Epagri scs112) ${ }^{1}$ & $846.17 \mathrm{a}$ & $187.11 \mathrm{a}$ & \\
\hline BMX Potência RR & $26.50 \mathrm{~b}$ & $0.15 b$ & $\mathrm{R}$ \\
\hline PELBR10-6049 RR & $13.33 b$ & $0.018 \mathrm{~b}$ & $\mathrm{R}$ \\
\hline BMX Icone IPRO & $4.83 b$ & $0.066 \mathrm{~b}$ & $\mathrm{R}$ \\
\hline TECIRGA 6070 RR & $0.33 b$ & $0.022 b$ & $\mathrm{R}$ \\
\hline BMX Valente RR & $0.17 \mathrm{~b}$ & $0.013 b$ & $\mathrm{R}$ \\
\hline CV (\%) & 46.33 & 45.59 & \\
\hline
\end{tabular}

${ }^{*}$ Means followed by the same letter in the same column are not significantly different, based on the Tukey test at $5 \%{ }^{* *}$ original values transformed into $[\sqrt{ }(\mathrm{x}+0.5)] ; \mathrm{R}=$ resistant; $\mathrm{S}=$ susceptible; $\mathrm{CV}=$ Coefficient of variation; $\mathrm{RF}=$ reproduction factor; ${ }^{1}$ indicates susceptible host.

was observed for most genotypes inoculated with Meloidogyne sp.0. Interaction between factors was verified by the evaluation of FMRS. In case of the effect of inoculation on FMRS within each genotype, interaction between factors was verified and a significant increase was observed in the genotypes BMX Icone IPRO, TECIRGA 6070 RR, and BMX Valente RR, inoculated with Meloidogyne sp.0. For

Table 3 - Response of soybean genotypes to Meloidogyne graminicola.

\begin{tabular}{|c|c|c|c|}
\hline \multirow[t]{2}{*}{ Genotypes } & \multirow[b]{2}{*}{ Number of galls ${ }^{* *}$} & Nematode- & \multirow[b]{2}{*}{ Response } \\
\hline & & $\mathrm{RF}$ & \\
\hline $\mathrm{ARROZ}^{1}$ & $393.17 \mathrm{a}^{*}$ & $19.81 \mathrm{a}$ & \\
\hline BRS 246 RR & $22 b$ & $0.43 b$ & $\mathrm{R}$ \\
\hline PELBR11-6038 RR & $12.5 \mathrm{c}$ & $0.38 \mathrm{c}$ & $\mathrm{R}$ \\
\hline PELBR11-6001 RR & $11.67 \mathrm{c}$ & $0.31 \mathrm{~d}$ & $\mathrm{R}$ \\
\hline PELBR10-6005 RR & $11.17 \mathrm{c}$ & $0.30 \mathrm{~d}$ & $\mathrm{R}$ \\
\hline BMX APOLO RR & $9.5 \mathrm{~d}$ & $0.29 \mathrm{~d}$ & $\mathrm{R}$ \\
\hline PELBR11-6028 RR & $8.83 \mathrm{~d}$ & $0.28 \mathrm{~d}$ & $\mathrm{R}$ \\
\hline PF11651 & $7.5 \mathrm{e}$ & $0.26 \mathrm{e}$ & $\mathrm{R}$ \\
\hline PF103251 & $6.17 \mathrm{e}$ & $0.25 \mathrm{e}$ & $\mathrm{R}$ \\
\hline PELBR11-6035 RR & $5.83 \mathrm{e}$ & $0.24 \mathrm{e}$ & $\mathrm{R}$ \\
\hline PELBR10-6050 RR & $5 e$ & $0.24 \mathrm{e}$ & $\mathrm{R}$ \\
\hline PELBR11-6042 RR & $3.33 \mathrm{f}$ & $0.23 \mathrm{e}$ & $\mathrm{R}$ \\
\hline PELBR10-6017 RR & $3.17 \mathrm{f}$ & $0.20 \mathrm{f}$ & $\mathrm{R}$ \\
\hline PELBR11-6007 RR & $3 \mathrm{f}$ & $0.16 f$ & $\mathrm{R}$ \\
\hline PELBR10-6016 RR & $2.67 f$ & $0.15 f$ & $\mathrm{R}$ \\
\hline PELBR10-6049 RR & $1.67 \mathrm{f}$ & $0.06 \mathrm{~g}$ & $\mathrm{R}$ \\
\hline CV $(\%)$ & 8.24 & 3.01 & \\
\hline
\end{tabular}

${ }^{*}$ Means followed by the same letter in the same column are not significantly different, based on the Scott $\&$ Knott test at $5 \%$; ${ }^{* *}$ original values transformed into $[\sqrt{ }(\mathrm{x}+0.5)] ; \mathrm{R}=$ resistant; $\mathrm{S}=$ susceptible; $\mathrm{CV}=$ Coefficient of variation; $\mathrm{RF}=$ reproduction factor; ${ }^{1}$ indicates susceptible host. 
M. javanica, the effects were significant only for genotypes and inoculation.

Gall formation was evident in all soybean genotypes inoculated with $M$. javanica. In plants inoculated with Meloidogyne sp.0, lower NG values were recorded for all genotypes. Based on RF analysis, all tested genotypes were found to be susceptible to $M$. javanica and resistant to Meloidogyne sp.0 (Table 2).

In the second experiment (Table 3), root galls were observed in all soybean genotypes; however, they presented reduced RF values $(0.06>$ $\mathrm{RF}<0.43$ ).

ASMUS and FERRAZ (2001) studied the relationship between $M$. javanica and soybean and reported little influence of $M$. javanica on the leaf chlorophyll content. The FMRS results of the present study were similar to those reported by these authors, and also to those of CARNEIRO et al. (1999), who found that the increase in FMRS was associated with the formation of root galls and the emergence of secondary roots.

Despite the reports of $M$. graminicola pathogenicity in soybean (LONG et al., 2017), the genotypes evaluated in the present study were resistant $(0.06>\mathrm{RF}<0.43)$. The genotypes included in this experiment, which assessed their susceptibility to the two root-knot nematode species, are currently cultivated in lowland regions, in rotation with irrigated rice. This study confirmed that these genotypes can be safely cultivated in this region, as they are resistant to both Meloidogyne sp.0 and M. graminicola.

\section{ACKNOWLEDGEMENTS}

This study was financed, in part, by the Coordenação de Aperfeiçoamento de Pessoal de Nível Superior - Brasil (CAPES) - Finance Code 001, the National Council for Scientific and Technological Development (CNPq: 409629/2016-2), and the Empresa Brasileira de Pesquisa Agropecuária (EMBRAPA)

\section{DECLARATION OF CONFLICT OF INTERESTS}

The authors declare no conflict of interest. The founding sponsors had no role in the design of the study; in the collection, analyses, or interpretation of data; in the writing of the manuscript, and in the decision to publish the results.

\section{AUTHORS' CONTRIBUTIONS}

JVAF, CBG, ACBO and LAYM conceived and designed the performed experiments. LAYM, DB, EH, ELN performed the experiments. The authors CBG and LAYM performed the statistical analysis. LAYM, JVAF and CBG prepared the manuscript. All authors reviewed and approved the final version of the manuscript.

\section{REFERENCES}

AGARWAL, D. K. et al. Soybean: introduction, improvement, and utilization in India-problems and prospects. Agricultural Research, v.2, n.4, p.293-300, 2013. Available from: < https://link. springer.com/article/10.1007/s40003-013-0088-0>. Accessed: Jun. 05, 2019. doi: 10.1007/s40003-013-0088-0.

ASMUS, G. L.; FERRAZ, L. C. C. B. Relações entre a densidade populacional de Meloidogyne javanica e a área foliar, a fotossíntese e os danos causados a variedades de soja. Nematologia Brasileira, Brasília, v.25, n.1. p.1-13, 2001. Accessed: Jun. 03, 2019.

CARNEIRO, R. G. et al. Carbon partitioning in soybean infected with Meloidogyne incognita and M. javanica. Journal of Nematology, Lake Alfred, v.31, n.3, p.348-355, 1999. Available from: <https://www.ncbi.nlm.nih.gov/pmc/articles/ PMC2620374/>. Accessed: May, 28, 2019.

COOLEN, W. A.; D'HERDE, C.J. A method for the quantitative extraction of nematodes plant tissue: Ghent, 1972. 77p.

DIAS, W. P. et al. Nematoides em soja: Identificação e Controle. Londrina: Embrapa Soja, 2010. 8p. (Circular Técnica, 76).

LONG, H. B. et al. First report of Meloidogyne graminicola on soybean (Glycine max) in China. Plant Disease, v.101, n.8, p.1554-1554, 2017. Available from: <https://apsjournals.apsnet. org/doi/full/10.1094/PDIS-03-17-0334-PDN>. Accessed: Jun. 04, 2019. doi: 10.1094/PDIS-03-17-0334-PDN.

MATTOS, V. D. S. et al. Caracterização de um Complexo de Espécies do Nematoide das Galhas Parasitando Arroz Irrigado na Região Sul do Brasil. Brasília, DF: Embrapa Recursos Genéticos e Biotecnologia, 2017. 28p. (Boletim de Pesquisa e Desenvolvimento, 331).

OOSTENBRINK, M. Major characteristics of the relation between nematodes and plants. Wageningen: Mededelingen Landbouwhogeschool, 1966. 6v.

SAS INSTITUTE. Statistical analysis system: release 9.3. Cary: Statistical Analysis System Institute, 2011. 